\title{
Slam Poetry Meets Classical Music
}

\author{
Axel Petri-Preis
}

Artists

Henrik Szanto, slam poetry

Jonas Scheiner, slam poetry

qWINDtett

Silvio Trachsel, oboe

Veronika Vitazkova, flute

Wolfgang Lücking, horn

Nikolaus Höckner, bassoon

Benjamin Schachinger, clarinet

Programme

Alexander von Zemlinsky: "Humoreske" (1941)

- Intro by Jonas and Henrik

Malcolm Arnold: Beginning of the $3^{\text {rd }}$ movement from "Three Chanties" (1943)

- Finnish Idioms

Darius Milhaud: Madrigal nocturne from "La Cheminée du Roi René" (1939) \& Eugène Bozza: "Scherzo" (1944)

- Wenn fliegen träumen lernen

Terence Greaves: “Mozart's Turkey Rock Mambo” (1993)

- Bathrobe

In their performance "Windrichtungen" (Wind Directions), the ensemble qWINDtett, a classical wind quintet, and the two slam poets Henrik Szanto and Jonas Scheiner bring together their respective art forms in a virtuoso manner. They have built a program where music and text stand in a reciprocal relationship, each commenting on, reflecting and complementing the other. 
When the slam poets and the musicians met each other for the first time, through the mediation of the Wiener Konzerthaus, the first thing they did was present each other with pieces of music and texts. Up to that stage, there had been only a few points of contact with each other's art form. In retrospect, this was a leap into cold water, but everyone involved very quickly became enthusiastic about the cooperation. So they sought for possibilities of how to bring music and slam poetry together. The rehearsals developed into a work in progress, combinations were found and discarded, new paths were taken. At the beginning, it was by no means clear what the final result would be. While at first it was very important to the musicians to present complete works, they subsequently began to use only excerpts or individual movements. In the final program, the music and the texts are performed one after the other or simultaneously, complete or in extracts, and thereby comment on, intensify or counteract each other.

Fig. 1: Henrik Szanto \& Jonas Scheiner performing at the lecture series, November 2019

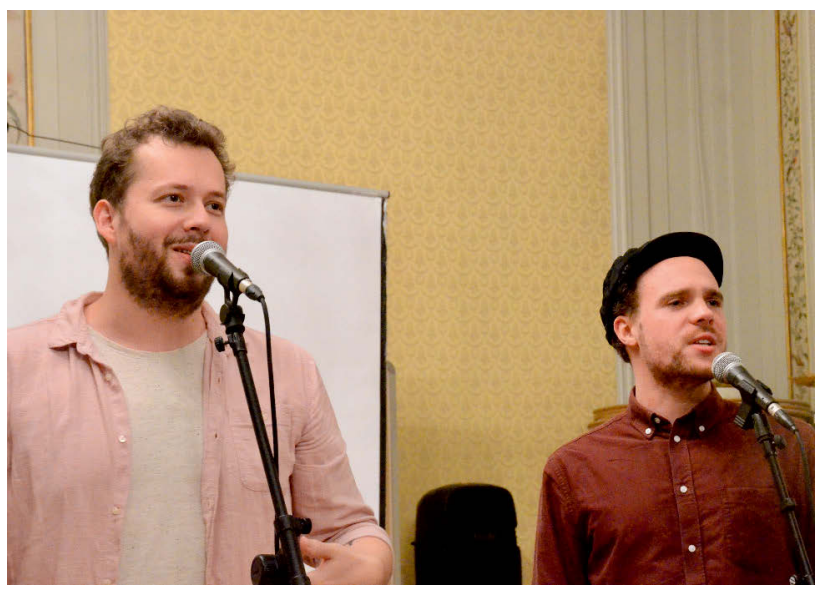

Source: private

The artists highlight two outcomes of their joint project: firstly, they found it valuable that their horizons were broadened by this collaboration, and that multiple learning processes were initiated on all sides. The improvisational way of rehearsing and developing the program, for example, proved to be irri- 
Fig. 2: The qWINDtett performing at the lecture series, November 2019

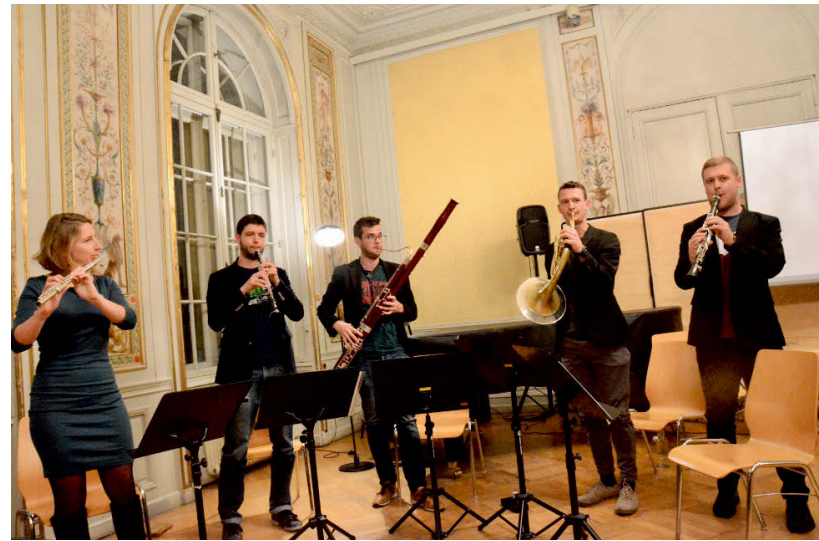

Source: private

tating for the musicians at first, but opened up new perspectives and a desire for unconventional concert formats. Secondly, their collaboration provided the possibility of bringing together different audiences that would otherwise not have met. In this way, both art forms, classical music and slam poetry, may have served as door openers for each other. Not least, the combination of text and music opens up a new level of perception, so that something third emerges, which text and music could not have achieved on their own.

\section{Biographical notes}

Jonas Scheiner and Henrik Szanto are writers, slam poets and organisers of cultural events in Vienna and Austria. They perform together under the name Kirmes Hanoi, and as such have become one of the most influential poetry slam teams in the German-speaking world, having won several regional, national, and international awards and championships. For the "Windrichtungen" project, Scheiner and Szanto curated the literature segment, for which they contributed their own pieces and will act as hosts during live performances. 
The qWINDtett, founded in Vienna, is a classical woodwind quintet in its formation. Its members - Desislava Dobreva (flute), Sebastian Sima (oboe), Benjamin Schachinger (clarinet), Nikolaus Höckner (bassoon) and Thomas Steinwender (horn) - come from Vienna, Lower Austria, Upper Austria, Salzburg and Bulgaria. They met in 2013 at the Angela Prokopp Summer Academy of the Vienna Philharmonic in Salzburg, since when their collaboration has continued. During their chamber music studies at the mdw University of Music and Performing Arts Vienna, the musicians' interplay was further refined. The ensemble has presented its by now large repertoire at the Vienna State Opera, the Musikverein Wien and also at the Wiener Konzerthaus. Together with the poetry slam collective FOMP, they performed as part of Music for You at the Wiener Konzerthaus and at Radio Kulturhaus Wien. 